\title{
WHYTE-OUT: HOW THE CREATOR OF GROUPTHINK BECAME UNSEEN BY MANAGEMENT'S HISTORY
}

\author{
OLIVER POL \\ School of Management \\ Victoria University of Wellington \\ PO Box 600 \\ Wellington 6140 \\ New Zealand \\ TODD BRIDGMAN \\ Victoria University of Wellington \\ STEPHEN CUMMINGS \\ Victoria University of Wellington
}

\begin{abstract}
Irving Janis' (1971) concept of 'groupthink', the idea that a desire for consensus overrides the realistic appraisals of alternatives and leads to poor decision making, is a staple of management textbooks. What has been forgotten, however, is that nearly 20 years before Janis' supposed invention, groupthink was created by William H. Whyte, author of one of the 1950s' most influential and popular books on management. We investigate how Whyte's link to groupthink became invisible to management's history, why this matters, and how recovering Whyte's ideas can provide critical new insights.
\end{abstract}

\section{INTRODUCTION}

Irving Janis, regarded as among the most eminent psychologists of the last century, noted in his 1971 article published in Psychology Today the tendency for people in groups to suppress contrary opinions because of the belief that high performing groups reach a consensus. Janis developed the groupthink concept by studying US foreign policy fiascos such as the Bay of Pigs invasion, the failure to anticipate the attack on Pearl Harbor, and the escalation of the Vietnam War. The policy makers that made these decisions were not stupid, Janis concluded. Their decision-making was clouded by "concurrence-seeking" dynamics (1971: 84) within the group that prevented a proper appraisal of alternative courses of action.

A recurring feature of management textbooks' representations of groupthink is the eight 'symptoms' that Janis derived from his case studies. In Victims of Groupthink (1972), Janis prescribes actions to mitigate these symptoms and these are also commonly repeated in contemporary textbooks. For example, once managers are aware of groupthink they can take action to overcome it by seeking external views or by encouraging a 'devil's advocate' role within the group.

However, if one traces the written record, it is clear that Janis did not coin the term groupthink. The credit for this should go to William H. Whyte, author of The Organization Man (1956), perhaps the first pop-management bestseller with two million copies sold. Groupthink was Whyte's diagnosis of the malaise affecting both the study and practice of management in the 
1950s. His concerns about the influence of group dynamics were shared by other influential scholars and these debates featured in both early histories of management and in textbooks.

It is surprising that Janis makes no mention of Whyte being the inventor of groupthink. It is also puzzling that despite it being well known in management studies until the 1970s that Whyte was the originator, by the time the first of the new-generation of management textbooks that emerged in the late 1970s and early 1980s appeared, the story had changed. Janis is credited as the creator of groupthink and Whyte's contribution is forgotten. Whyte's work on groupthink is now almost invisible in the history of management.

There has been no sustained attempt to explore and explain this 'Whyte-out' - and that is the task we set ourselves for this paper. We are inspired by the growing interest among Critical Management Studies scholars in critiquing conventional management history narratives (Bell \& Taylor, 2013; Bridgman, Cummings, \& Ballard, 2019; Carroll, Firth, Ford, \& Taylor, 2016; Cummings, Bridgman, Rowlinson, \& Hassard, 2017; Durepos \& Mills, 2012; Fougère \& Moulettes, 2012; Jacques \& Durepos, 2015). In particular, we have been drawn to the utilization of the archaeological and genealogical approaches of French philosopher and 'counter-historian' Michel Foucault (1980) to dig into the wider structural context and power/knowledge relations that frame what those creating historical narratives see as important and what gets forgotten.

\section{A COUNTER-HISTORY OF THE CONVENTIONAL ORIGINS OF GROUPTHINK}

In 1952, Fortune published Whyte's article "Groupthink" as part of the magazine's 'Communication' series. He wrote of his concern at the increasing consensus that the individual had no meaning except as a group member. To describe this philosophy, he introduces the term groupthink: "a coinage - and, admittedly, a loaded one" (1952a: 2); and provides a working definition:

We are not talking about mere instinctive conformity - it is, after all, a perennial failing of mankind. What we are talking about is a rationalized conformity - an open, articulate philosophy which holds that group values are not only expedient but right and good as well. (1952a: 2)

The Fortune article laid the foundation for the work Whyte is best-known for, The Organization Man, one of a number of books published in the 1950s that questioned the supposed Golden Age of post-war America, where large organizations provided the opportunity for career progression and a safe and settled suburban life. Whyte was dismayed that the book's protagonist, the 'organization man', had accepted his situation willingly. He comfortable and had convinced himself it was good for him.

The Organization Man followed David Riesman's The Lonely Crowd (1950) a sociological analysis of American culture and C. Wright Mills' (1951) White Collar studies of the American middle class. It was published the same year as Mills' The Power Elite (1956a) and was followed by John Kenneth Galbraith's (1958) critique of the so-called 'affluent society'. The Organization Man also chimed with social scientists who were challenging the structure and dynamics of bureaucracy (Blau, 1956; Gouldner, 1954; Merton, 1957).

Groupthink is not mentioned in the book, with Whyte preferring the term 'social ethic'. The three features of the social ethic were a belief in the group as a source of creativity; a belief in belongingness as the ultimate need of the individual; and a belief in the application of science 
to achieve this belongingness. Whyte detested the obsession with work groups. Consensus should not be the overriding goal, he argued, since progress tended to come from challenging the dominant, taken-for-granted view. Whyte saw universities as complicit in this indoctrination process - they were breeding a generation of bureaucrats. This was reflected in the rise of vocational training and the decline of a liberal, intellectual education.

Whyte's primary target in this regard was the field of Human Relations, which had developed at Harvard Business School during the interwar period. By the start of the 1950s Human Relations had come to dominate the HBS curriculum and had become influential in industry, its central tenets sold by a rapidly growing cadre of organizational psychologists. Particularly influential were applications of group dynamics, based on the work of Kurt Lewin. Whyte was annoyed by claims that scientific evidence had proven the group to be superior to the individual. He didn't believe the science. If you analyzed problems in organizations only through the lens of group dynamics, he said, you would diagnose it as disharmony within the group. This might be true, but it might also be missing the real cause. For Whyte, Human Relations had become a moral crusade rather than a scientific endeavor.

In management studies writing in this period, the 1950s was characterized by unease about the increasing size and power of big business. Conformity was of great interest, and as the stress placed on the value of group work grew within organizations, so did the number of writers concerned about the drift away from individualism. Peter Drucker launched an excoriating critique of Human Relations in The Practice of Management (1954). Like Whyte, Drucker thought the focus on groups was excessive and had failed to acknowledge questions of power and a clash of interests which could not be wished away by largely empty slogans such as 'the happy worker is a productive worker'. Drucker believed Human Relations had developed "an almost panicky fear of the labor union" (279) and a "strongly manipulative tendency" (279) to diagnose any rational opposition to management as the result of maladaptive individuals.

These themes were picked up by Baritz in The Servants of Power (1960). Baritz observed that as Human Relations' popularity grew it had become almost impossible for managers to resist: "One either authorized human-relations research or was made to feel like an anachronism left over from the Neolithic period." (173). Baritz believed the obsession with the group as the unit of analysis was a divide and conquer strategy by management and enabled management to hoodwink employees into believing that they had been involved in decision making. He saved his strongest criticism for industrial psychologists, who he alleged had abandoned their wider obligations to society as intellectuals and sold their knowledge and their soul to the corporation.

While Human Relations with its emphasis on group dynamics had many high-profile critics, there were also those who leapt to its defense, creating a vibrant debate within scholarly and practitioner communities. Both of Whyte's 1950s books were perceived as radically antibusiness, and his concerns about the dominance of groups were said to be over-exaggerated (Baumgartel, 1963; Tannenbaum, 1959).

\section{WHY JANIS PREVAILED AS THE FOUNDER OF GROUTHINK}

Whyte's writing on groupthink established him as an authority on management in the 1950s, which was amplified by the publication of The Organization Man. Groupthink was picked up by a newly emergent textbook genre. Harold Leavitt's first edition of Managerial Psychology (1958) notes a "growing vanguard of "group-thinkers"" (190) and includes a reference to Whyte. Leavitt comes to a similar conclusion to Whyte, noting the danger of the 
notion that groups must be happy to be productive, and pinpointing happiness as a precursor to conformity. Vance's Industrial Administration (1959) stressed the importance of groupthink as a contribution, expressing concern about the belief that groups should take over control of decision making.

Over the next two decades however, recognition of Whyte's role in developing the concept ebbed away. Despite the significant impact his conceptualization of groupthink had on the field of management studies in the 1950s, management textbooks today make almost no mention of the alternative history of the origins of groupthink we have presented. Why does management studies (including Critical Management Studies) not recognize Whyte as the founder of groupthink? Why has he been sidelined? We identified three contributing factors.

The first concerns Whyte's career trajectory. The Organization Man caused a sensation when it was published but by this time, Whyte was ready to move on. He started writing about city planning and business while at Fortune and commissioned Jane Jacobs to write articles that were a precursor to her classic book The Death and Life of Great American Cities (1961). Disappointed not to have been chosen to be Fortune's managing editor, he left in 1959 to focus on urban planning issues, especially as they related to conservation (Birch, 1986; Nocera, 2002). Whyte spent the next 40 years until his death in 1999 observing and improving America's landscape and cities. While Janis' groupthink was catching alight, Whyte spent much of 1972 in New York, sitting in plazas and watching pedestrians, pining for big trees and accessible water features (Whyte, 1972).

A second explanation for the 'Whyte-out' relates to changes in management textbook publishing. Many of the best-known and best-selling management textbooks of today were first published in the late 1970s and early 1980s (e.g., Baron, 1983; Robbins, 1979; Wheelen \& Hunger, 1983). But later editions took on a new appearance in the 1980s. One change was the insertion of frameworks that could be easily applied by students to managerial situations. Frameworks made teaching to increasingly large groups of management students easier (in the next decade slide packs associated with texts would start to be promoted). At the same time, they made the subject look both scientific and practically applicable.

While Janis was not writing for the management studies community and did not anticipate that groupthink would be picked up by them, he crafted his work in a way that appealed. The use of historical case studies provided textbooks with ready-made cases that brought the theory to life. His creation of eight symptoms, although motivated by a desire to assist empirical testing of his hypotheses, were an easily-applied diagnostic framework for managers. While Janis highlights a potential limitation of working in groups, his concept also comes with a set of symptoms and prescriptions that can form part of a manager's problemsolving 'tool-kit' to overcome groupthink and to capture the benefits of working in groups and teams. Given all these positives, it is unsurprising that textbooks were happy to look past the absence of empirical validation for Janis' theory. Nearly forty years on there is not a single credible, influential study showing a positive relationship with all of Janis' symptoms, despite numerous attempts.

Just as it is easy to see why Janis's concept of groupthink appealed to management textbooks, it is also easy to see why Whyte's did not. Mainstream management textbooks explore the subject from the perspective of the manager and cast the role of management in a positive light. Would the fledgling academic sub-field of group dynamics want to recognize as one of its key contributors somebody who opposed its very existence? Who saw group working as a problem for organizations rather than an opportunity for improving performance? And who 
criticized business schools for creating docile subjects to serve the narrow interests of corporations (Starbuck, 2003; Beder, 2006)? We think not.

Our third Whyte-Out explanation is that the critique of group dynamics that raged so intensely in the 1950s faded away. Just as Whyte's personal interests evolved in a direction away from his writing on groupthink, so too did Human Relations evolve in a way that obscured Whyte's hand. The campaign that Whyte so disapproved of succeeded, with Whyte increasingly out of step as the consensus shifted toward the deeper embrace of big business. In this environment it is no wonder that Janis' 'softer' study was preferred as a foundation for management studies, despite this coming 20 years later and from another intellectual field.

Whyte's sidelining in the history of management is well illustrated by examining successive editions of Wren's The Evolution of Management Thought, the field's seminal history text. In the first edition (1972) Wren devotes an entire chapter to criticisms of Mayo's experiments at Hawthorne and the development of Human Relations as a field. Included is a section 'Conclusions regarding social man' that begins with McMurray's (1958) article in Harvard Business Review which argued that organizational innovation can be stifled by group pressures, because of members' desire to conform to the group and their reluctance to voice disagreement. Wren notes that "William $\mathrm{H}$. Whyte has also decried the exaltation of the group to the detriment of the individual" (378). Wren then details McNair's (1957) complaint that Human Relations treats people like children, suppresses individual responsibility, creates conformity to the group and over-emphasizes the importance of people skills to effective executive leadership. Wren concludes this section by discussing the evangelism and mysticism that characterized Human Relations training.

Wren's second edition (1979) contains the same material as the first edition, but there is a significant shift in the third edition (1987). The title of the chapter changes from 'Social man and the critics' to 'Human relations in concept and practice'. The section 'Conclusions regarding social man' disappears. McNair's (1957) critique is retained as part of a new section 'The premises of an industrial civilization', but absent from this edition and all subsequent ones are McMurray's and Whyte's concerns about the dangers of conformity in groups. The debate that had energized the nascent field of management studies in the 1950s had subsided, obscuring Whyte's hand in the creation of groupthink.

\section{CONCLUSION: WHY BRINGING WHYTE BACK MATTERS NOW}

We have outlined two quite different versions of the groupthink concept. On the surface it may appear that Janis' version is the one more suited to today's free-flowing world of work, where people are less likely to belong to one organization in the way that they may have when Whyte wrote (Hanson \& O'Donohue, 2010). On this view, the only relevant recommendation that our paper should elicit in response to the Whyte-out is to re-instate his rightful place in the historical record as founder of the groupthink concept. We believe this would be a good start, but we also argue there are two deeper and more impactful reasons for bringing Whyte back. These apply not just to the past, but to our present and future understanding of management.

First and foremost, we believe that compared with Janis, Whyte's writing on groupthink and the system that made employees susceptible to it, is a more insightful and disruptive lens with which to look at modern organizational and social dynamics critically. The imagery of the employees devoting their lives to one organization for their career (so often associated with Whyte's work) is an anachronism. But the subtle power dynamics that Whyte describes 
(whereby the notion of the good of the group is used as a means of suppressing the creativity, power and free-will of the individual) is at least as relevant, and more insidious and difficult to see, in today's 'gig economy'.

Whyte's view of groupthink - as a deep-seated and creeping social issue to be opposed; rather than the view taken from Janis - something positive if it is handed over to and handled by capable managers - is a more critical and contemporary lens to introduce to management scholars. It may seem odd that critical management thinking could benefit from looking so far back, into a world that we have come to characterize as a time when there was less ferment about the role of organizations then there is today. But we have shown this categorization to be inaccurate. Thinking critically about management practices was likely far more in the mainstream in the 1950s then it is now. As a result, looking back into that world can provide novel insights for critical management scholars, and indeed management scholars more broadly.

The second reason for bringing Whyte back into focus is that his marginalization is an example of how unpalatable ideas are often obscured in the histories that are accepted by scholars in our field and projected to management students via textbooks. Even though many of the early techniques that were gathered into what came to be known as Scientific Management were clearly developed on American slave plantations, we see little trace of this in management history and in management textbooks. Why has the pioneering work of Mary Parker Follett never been fully grasped? Why have the deep flaws in Elton Mayo's work never unsettled his position as a management pioneer? Why are there so few African-American or Latino faces in the histories of management that appear in textbooks? While we can find fragments of work aiming to re-awaken our interest in these 'side-bars' of history (e.g., Cooke, 2003, and Rosenthal, 2018, on slavery; Hassard, 2012, on Mayo; O'Connor, 2000, and Tonn, 2008, on Follett; Prieto \& Phipps, 2019 on African-American management pioneers); the case of Whyte's marginalization provides further grist to this mill. We hope it encourages others to look further into the reasons behind management's desire for a bland, affirming and homogenous past and the costs of projecting it.

Understanding that Whyte came before Janis, and why, despite this, management remembers the latter and not the former; helps us to see through the ensuing Whyte-out and recommend three things. First, that William $\mathrm{H}$. Whyte be granted his rightful place as the originator of the concept of groupthink in management studies. Second, that his lens for examining the effects of groupthink be taught to more students and adopted by more scholars. And third, that Whyte's treatment by management's conventional history be seen as further evidence as to why we should do more to think critically about the history of management studies that has been bestowed to us.

\section{REFERENCES AVAILABLE FROM THE AUTHORS}

